\title{
ANTIBIOTIC MSD-819. PREPARATION AND PROPERTIES OF BIOLOGICALLY ACTIVE DERIVATIVES
}

\author{
Thomas W. Miller, A. Kathrine Miller, Frank J. Wolf, \\ Edward O. Stapley and David Hendlin \\ Merck Sharp \& Dohme Research Laboratories and \\ Merck Institute for Therapeutic Research \\ Rahway, New Jersey, U. S. A.
}

(Received for publication April 28, 1969)

\begin{abstract}
Seven derivatives of 6-chloro-2-quinoxalinecarboxylic acid 1,4-dioxide were prepared. These include esters, amides and the acid hydrazide. The derivatives were tested against fifteen bacteria by agar diffusion assay and against two bacterial infections in vivo. Increased effectiveness on oral administration was observed with the carboxamide.
\end{abstract}

The production, biological characterization, chemical characterization and structure of MSD-819 (6-chloro-2-quinoxalinecarboxylic acid 1,4-dioxide) have been reported elsewhere $e^{2,3)}$. The preparation and testing of seven derivatives of the antibiotic are reported in this paper.

Esters

Since MSD-819 undergoes decarboxylation in acid solution, esterification with acid catalysts is not practical. The methyl ester (Compound 2) was prepared by using diazomethane as reported elsewhere ${ }^{2)}$. Other derivatives were prepared from this compound. The $n$-butyl ester (Compound 3) was prepared by trans-esterification with an alkaline catalyst.

Amides

The carboxamide (Compound 4) and the N-substituted amides were prepared by adding the appropriate base to a methanol solution of the methyl ester. The addition of ammonia yielded the carboxamide; methylamine, the $\mathrm{N}$ methylcarboxamide (Compound 5); hydroxylamine, the $\mathrm{N}$ hydroxycarboxamide (Compound 6); and ethanolamine, the $\mathrm{N}$-hydroxyethylcarboxamide (Compound 7).

Acid Hydrazide

The acid hydrazide (Compound 8) was prepared by adding hydrazine hydrate to a methanol solution of the methyl ester. The structural formulas of these derivatives are shown in Fig. 1.

\section{Materials and Methods}

n-Butyl-6-chloro-2-quinoxalinecarboxylate 1,4-dioxide (Compound 3)

One hundred $\mathrm{mg}$ of the methyl ester of MSD-819 was suspended in $100 \mathrm{ml}$ of $n$-butyl aicohol and $1 \mathrm{ml}$ of tri-
Fig. 1. Structure of derivatives<smiles></smiles>

\begin{tabular}{cll} 
Compound No. & & $\mathrm{X}$ \\
\cline { 1 - 1 } 1 & & $-\mathrm{ONa}$ \\
2 & & $-\mathrm{OCH}_{3}$ \\
3 & & $-\mathrm{OC}_{4} \mathrm{H}_{9}$ \\
4 & & $-\mathrm{NH}_{2}$ \\
5 & & $-\mathrm{NHCH}_{3}$ \\
6 & & $-\mathrm{NHOH}^{2}$ \\
7 & & $-\mathrm{NHC}_{2} \mathrm{H}_{4} \mathrm{OH}$ \\
8 & & $-\mathrm{NHNH}_{2}$
\end{tabular}


ethylamine was added. The mixture was stored in the dark for 4 days and shaken occasionally. The resulting clear solution was concentrated to dryness and the residue was crystallized from $10 \mathrm{ml}$ of methanol. Yield : $57 \mathrm{mg}(50 \%)$. The product was examined by thin-layer chromatography using silica-G plates and developing with chloroformmethanol $(19: 1)$. The spots were detected by observing their fluorescence under ultraviolet light. The $R_{\mathbf{f}}$ of the methyl ester was 0.30 and that of the $n$-butyl ester 0.45 . Only a trace of the starting material was observed in the product.

6-Chloro-2-quinoxalinecarboxamide 1, 4-dioxide (Compound 4).

A $675 \mathrm{mg}$ sample of methyl ester was dissolved in $675 \mathrm{ml}$ of methanol and filtered. Six $\mathrm{ml}$ of concentrated aqueous ammonia was added and the mixture was stirred 3 hours. The precipitate was collected on a filter, washed and dried. Yield : $489 \mathrm{mg}(76 \%)$.

6-Chloro-N-methyl-2-quinoxalinecarboxamide 1, 4-dioxide (Compound 5)

A filtered solution of $215 \mathrm{mg}$ of methyl ester in $180 \mathrm{ml}$ of methanol was sparged with methylamine for 20 minutes while stirring, stirred $1 / 2$ hour and refrigerated $1 / 2$ hour. The product was collected on a filter, washed and dried. Yield : $189 \mathrm{mg}(88 \%)$.

6-Chloro-N-hydroxy-2-quinoxalinecarboxamide 1,4-dioxide (Compound 6)

Hydroxylamine was prepared by mixing $420 \mathrm{mg}$ of hydroxylamine hydrochloride in 5 $\mathrm{ml}$ of methanol and $320 \mathrm{mg}$ of sodium methoxide in $5 \mathrm{ml}$ of methanol and filtering off the precipitated $\mathrm{NaCl}$. The filtrate was added to a filtered solution of $200 \mathrm{mg}$ of methyl ester in $200 \mathrm{ml}$ of methanol and stirred for 3 hours. The orange product was collected on a filter, washed and dried. Yield : $130 \mathrm{mg}$ (65\%). A sample was prepared for microanalysis by dissolving $20 \mathrm{mg}$ in $2 \mathrm{ml}$ of water by adding $0.1 \mathrm{~N} \mathrm{NaOH}$ until pH 10 was reached. The solution was filtered and neutralized with $0.1 \mathrm{~N}$ acetic acid. The product was collected on a filter, washed and dried. Yield : $15 \mathrm{mg}(75 \%)$.

6-Chloro-N-(hydroxyethyl) 2-quinoxalinecarboxamide 1, 4-dioxide (Compound 7)

Ethanolamine $(0.1 \mathrm{ml})$ was added to a filtered solution of $200 \mathrm{mg}$ of methyl ester in $200 \mathrm{ml}$ of methanol and allowed to stand for 4 days. The product was collected on a filter, washed and dried. Yield : $69 \mathrm{mg}(30 \%)$. The filtrate was concentrated to dryness and slurried in $10 \mathrm{ml}$ of methanol. The product was collected on a filter, washed and dried. Yield : $68 \mathrm{mg}(30 \%)$. The two products were combined and recrystallized from $200 \mathrm{ml}$ of ethanol. Yield : $104 \mathrm{mg}(46 \%)$.

6-Chloro-2-quinoxalinecarboxylic acid hydrazide 1, 4-dioxide (Compound 8)

One-half $\mathrm{ml}$ of hydrazine hydrate in $10 \mathrm{ml}$ of methanol was added to a filtered solution of $200 \mathrm{mg}$ of methyl ester in $200 \mathrm{ml}$ of methanol and stirred for 2 hours. The product was collected on a filter, washed and dried. Yield : $186 \mathrm{mg}(93 \%)$. A sample for microanalysis was prepared by recrystallizing $72 \mathrm{mg}$ from $20 \mathrm{ml}$ of glacial acetic acid. Yield : $58 \mathrm{mg}(80 \%)$.

All of the derivatives were characterized by microanalyses and satisfactory values for carbon, hydrogen and nitrogen were obtained.

Assay Procedures

Initial in vitro assays were performed by the disc-plate agar diffusion method using $13 \mathrm{~mm}$ discs and Proteus vulgaris $\mathrm{MB}-838$ as the organism. The concentration which gave a $30 \mathrm{~mm}$ inhibition zone in the assay was used for determination of antibacterial spectra. These were determined by the same method except $7 \mathrm{~mm}$ discs were used. The results are reported in Table 1.

In vivo Activity

The derivatives, except for the acid hydrazide, were tested in mice and the results are shown in Table 2. Female white Swiss mice weighing $19 \sim 21 \mathrm{~g}$ were infected intraperitoneally with $5 \sim 50 \mathrm{LD}_{50}$ doses of test organism and treated by the indicated route at the time of infection and again six hours later. Five infected mice were used at each of the four-fold increments of the test material and two uninfected mice were used for 
Table 1. Antimicrobial spectra of derivatives of MSD-819.

Inhibition zone diameters with $7 \mathrm{~mm}$ discs.

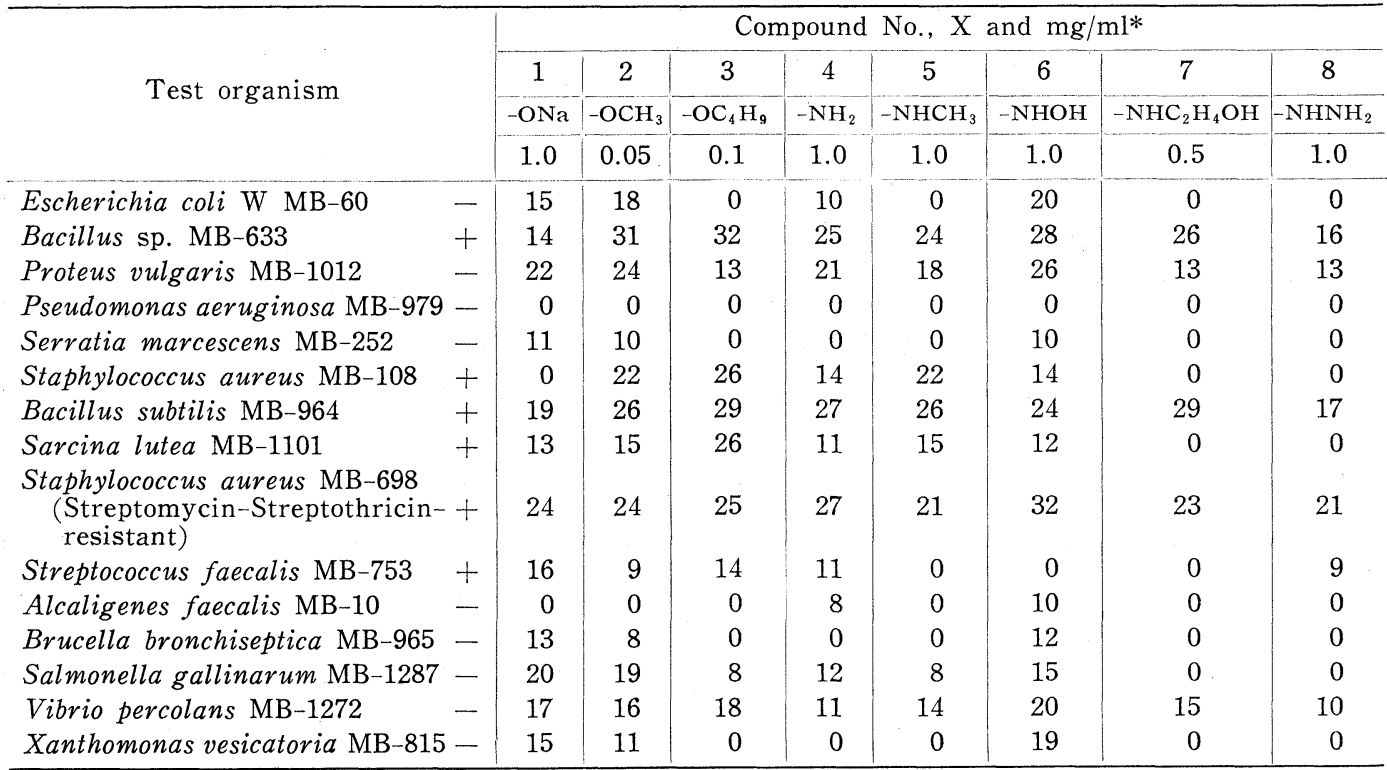

* 1 was dissolved in water, 2 and 3 in $10 \%$ methanol; 4, 5, 6 and 8 in 5\% DMSO.

7 was dissolved in methanol and the discs were dried.

Table 2. Activity of derivatives of MSD-819 in protecting mice against infection, $\mathrm{ED}_{50}(\mathrm{mg}$ per dose)

\begin{tabular}{|c|c|c|c|c|c|c|c|c|}
\hline \multirow{2}{*}{ Test organism } & \multirow{2}{*}{$\begin{array}{c}\text { Therapy } \\
\text { route }\end{array}$} & \multicolumn{7}{|c|}{ Compound No., $\mathrm{X}$ and $\mathrm{ED}_{50}(\mathrm{mg} / \mathrm{dose})$} \\
\hline & & $\begin{array}{c}1 \\
-\mathrm{ONa}\end{array}$ & $\stackrel{2}{-\mathrm{OCH}_{3}}$ & $\begin{array}{c}3 \\
-\mathrm{OC}_{4} \mathrm{H}_{9}\end{array}$ & $\begin{array}{r}4 \\
-\mathrm{NH}_{2} \\
\end{array}$ & $\begin{array}{c}5 \\
-\mathrm{NHCH}_{3} \\
\end{array}$ & $\begin{array}{c}6 \\
-\mathrm{NHOH} \\
\end{array}$ & $\begin{array}{c}7 \\
-\mathrm{NHC}_{2} \mathrm{H}_{4} \mathrm{OH}\end{array}$ \\
\hline \multirow[t]{3}{*}{ Proteus vulgaris 1810} & I. P. & 0.2 & 0.17 & $>2.0$ & 0.06 & 0.15 & 0.5 & 0.5 \\
\hline & S. C. & $>2.0$ & & & & & & \\
\hline & P. 0. & $>2.0 *$ & $>2.5$ & & 0.47 & $>2.0$ & & \\
\hline Staphylococcus aureus 2949 & I. P. & 0.67 & & & 0.85 & & & \\
\hline Tolerated & I. P. & 2 & 0.5 & 2 & 1 & 2 & 1 & 1 \\
\hline Toxic & I. P. & 4 & 2.0 & $>2$ & 4 & $>2$ & $>1$ & $>1$ \\
\hline Tolerated & P. O. & 2 & 2.5 & & 4 & 2 & & \\
\hline Toxic & P. $\mathrm{O}$. & $8 * *$ & 10 & & $>4$ & $>2$ & & \\
\hline
\end{tabular}

* Prolonged survival time but did not protect

** Borderline, 1 of 2 mice surviving.

toxicity. Controls of the virulence of the test organism were included in each test and penicillin $G$ was used as a standard compound. All untreated control mice died within 36 hours of infection. Surviving, drug-treated mice were checked daily for seven days at which time the test was considered complete and the amount of drug required to protect $50 \%$ of the infected mice $\left(\mathrm{ED}_{50}\right)$ was calculated by the method of $\mathrm{K}_{\text {NUDSON }}{ }^{1)}$. Since only two mice were used for toxicity, this method is not applicable and the results are shown as the maximum tolerated dose and the toxic dose.

The sodium salt was dissolved in water for testing and the derivatives were given as aqueous suspensions.

\section{Results and Discussion}

In the initial assays against Proteus vulgaris MB-838, the slope of the dose 
response when plotted as a semi-logarithmic function was 4 for the sodium salt and about 3 for the derivatives, thus indicating that the derivatives do not diffuse as readily as the original antibiotic. Since the dose-responses of the compounds are not uniform, strict comparison of potencies based on disc assays is not possible, however, some generalizations can be made. The methyl ester is at least 20 times as potent as the sodium salt against most of the organisms tested, since a solution of $1 / 20$ th concentration gives zones equal to or greater than those observed with the sodium salt.

The antibacterial spectra of the derivatives are shifted in favor of activity against gram-positive organisms. This is especially true of the esters which give rather large zones against most gram-positive organisms at lower concentration than that used for the sodium salt.

The in vivo results show that only the carboxamide had oral activity against Proteus vulgaris at the levels tested, and the oral to intraperitoneal ratio was about 8 in this one test. A second test showed a ratio of about 14 . The other derivatives were not tested at high enough concentrations to state that they were inactive orally at this higher ratio. The sodium salt, however, in one test, was not active orally at a level more than 70 times the effective intraperitoneal dose for Salmonella schottmuelleris ${ }^{3}$.

Since the butyl ester, the $\mathrm{N}$-hydroxyamide and the $\mathrm{N}$-(hydroxyethyl)-amide were less effective than the other compounds by the intraperitoneal route, they were not tested orally nor were they tested at high enough levels to detect toxicity.

\section{Acknowledgment}

We wish to express our appreciation to various members of Merck Sharp \& Dohme Laboratories and Merck Institute for Therapeutic Research who contributed to this work. In particular, we wish to thank Richard N. Boos and his associates for microanalyses and Edward Hendrzak, Helmut Kropp, Ann Germain and Ruth Baldwin for technical assistance.

\section{Literature Cited}

1) Knudson, L. F. \& J. M. Curtis : The use of angular transformation in biological assay. J. Am. Stat. Assoc. $42: 282 \sim 296,1947$.

2) Miller, T. W.; R. W. Walker, N. R. Trenner, B. A. Arison \& F. J. Wolf : Antibiotic MSD819. II. Isolation and chemical characterization as 6-chloro-2-quinoxalinecarboxylic acid 1,4dioxide. Antimicr. Agents \& Chemoth.-1968 (in press)

3) Stapley, E. O.; D. Hendlin, J. M. Mata, A. K. Miller, M. Jackson \& H. Wallick : Antibiotic MSD-819. I. Microbial production and biological characterization. Antimicr. Agents \& Chemoth.-1968 (in press) 